\title{
Millenial Generation's Online Behavior in the humanity of the Pancasila
}

\author{
R. Machfiroh \& M.F.A. Zahra \\ Telkom University, Bandung, Indonesia
}

\begin{abstract}
The development of digital technology as a feature of globalization has shortened distance, space, time, and is inevitable. Indonesian citizens as internet users are always increasing. This study analyzed the development of digital citizenship in Indonesia and whether it can provide an alternative solution in the establishment of digital citizenship. The method used in this research was case study. The data collection techniques used questionnaires and interviews with junior high school students in Bandung, Indonesia, with a sample of 450 people. Data analysis was descriptive analytics. The results indicate that the millenial generation's online behavior, in the humanity of the Pancasila, still needs to be improved regarding digital etiquette competence, through group power in social media "who controls social media, he controls the world" to make it happen. The implications are to reconstruct rules of use and users of social media and appropriate educational models for digital citizens.
\end{abstract}

Keywords: civic education, digital era, online behaviour, millenial generation, humanity of the Pancasila

\section{INTRODUCTION}

Based on Van Dijk's research, presented at the Sharing Session event at Directorate of Research and Community Service of Telkom University in 2015, the number of internet users in Indonesia increases every year, reaching 19.460 million as of 2015. Indonesia experienced a sharp increase associated with the use of Information Communication Technology ICT. However, currently only part of Indonesia is on the level of the digital world used for education and employment. Other influences result from the exposure of negative access to children and adolescents with bad information flooding the internet (Setiawan 2009). Shock culture and the influence of bad information construct Indonesian citizens' low attitude of communication, tolerance, and care, while in this current digital era the value to be upheld is tolerance and care for others. Education is one of the principal pillars to the development of moral quality (Komalasari 2017).

The rapid development of technology had an impact on the behavior and character of people who lived the area. Junior high-school adolescents, the object of this research and based on theories, fall into the birth category of 2001-2010. Characteristics of generation $\mathrm{Z}$ are being able to describe actual conditions occurring to and serving adolescents. They also have an instant mindset, are technology dependent, tend to be popular in social media, have minimal social interaction power, and even manage to be individualistic (Renzulli, available at https://goo.gl/cTymz4, accessed on December 10, 2018). Therefore, it is foreseen that teenagers use the internet not to find learning resources, but to stream and play social media. Line/WhatsApp, Instagram, Twitter, and Facebook are favorite social media sites. However, there was an imbalance between digital knowledge and skills, and the ability to operate them fully. 


\section{RESEARCH METHOD}

The research approach used in this case study is the descriptive analytics method. Data collection techniques used books, journal articles, research studies, and other materials are related to the impact of the development of information technology, digital citizenship, the civilization of Indonesian citizenship, including interviews with students, teachers of civics educations, headmasters, observations, and documentations. Data was analyzed after data reduction was done, followed by data presentation, data verification, and conclusion.

\section{DISCUSSION}

Digital citizenship in Indonesia discusses "internet usage and digital safety". Globalization demands civic education to develop civic competence involving civic knowledge, civic skills, and civic disposition, which are multidimensional (Komalasari 2009). Technology is a catalyst of change, making change to be revolutionary, very fast, and intense (Suryadi 2006). However, the positive side of the world of education and knowledge, is that revolution is happening and has double dimension that connects astonishing modern brain research with the power of information and knowledge that can be accessed quickly and easily through information and communication technology. Suryadi (2006) asserts that the joint revolution of the internet-computer-World Wide Web has formed a new generation, with new values, new social styles, new cultures, and even new economies called the digital economy.

Indonesia, with a population of 290 million people, has $51.5 \%$ of internet users, a great potential for citizen development in the digital age. Research by Machfiroh (2016) indicated that $85 \%$ of junior high-school students in Bandung City are mobile phone users. APJII research in 2016 showed that $18.4 \%$ of internet users in Java Island are aged between 10-24 years old. In the United States, the PEW research results showed that $75 \%$ of kids aged $12-17$ years old have smartphones (White 2016). However, between the United States and Indonesia there are differences in security and safety. In the United States, parents supervise their children's mobile phone usage for $36 \%$ of the time, but in Indonesia this supervision is still low. Currently, parents or teachers are experiencing gadget addiction. Children who do not get enough parenting acts, due to parents who get addicted to their digital devices, grow up with negative emotions and cannot control sadness, anxiety, or even anger. Developed countries, such as Germany and Finland, have limited the use of mobile phones for children.

It is in accordance with Buckingham (2000) that many children lose their childhood due to consuming too much electronic media in the form of adult material, so that children quickly become adults. Teenagers are already able to operate the internet and can upload content, but are not accompanied by the ability to create their own content. Therefore, it is common for teenagers to just "copy-paste". Such an attitude indirectly accustoms teenagers to acts of plagiarism toward other people's work without mentioning sources. The characteristics of adolescents of junior highschool age are at the stage of showing their existence; they like to look for wise words/quotes without trying to construct their own thoughts on the things being quoted. They are also lacking the ability to cross-check data regarding information obtained on the internet. The implication is that the information shared by teenagers on social media can become a means of spreading hoaxes for free. To see the digital skills of adolescents, the following will explain the triangulation results based on three data collection techniques (Table 1).

Along with this phenomenon, speaking textually in the digital era is needed. Teenagers act not only as users but also producers (pioneers) of news useful to others, as well as making themselves exist in social media. In this connection, the skills of adolescents as the subject of knowledge construction need to be continuously built. Some of the skills that teenagers must-have in the digital era include (a) operational skills, (b) formal skills, (c) information skills, (d) communication skills, (e) strategic skills, and (f) content creation skills (Van Dijk 1999, 2012). 
Table 1. Triangulation of digital skills based on data collection techniques.

\begin{tabular}{lll}
\hline Interview & Observation & Documentation \\
\hline $\begin{array}{l}\text { Cellphones and social media are } \\
\text { not only a lifestyle but a neces- } \\
\text { sity for adolescents. Social media } \\
\begin{array}{l}\text { is a means of actualization and self- } \\
\text { expression for teenagers. }\end{array}\end{array}$ & $\begin{array}{l}\text { Teens are often caught access- } \\
\text { websites, rather than looking } \\
\text { for study materials. }\end{array}$ & $\begin{array}{l}\text { The results showed that children } \\
\text { mindsed, depend on technology, } \\
\text { and seek popularity through social } \\
\text { media channels. }\end{array}$ \\
\hline
\end{tabular}

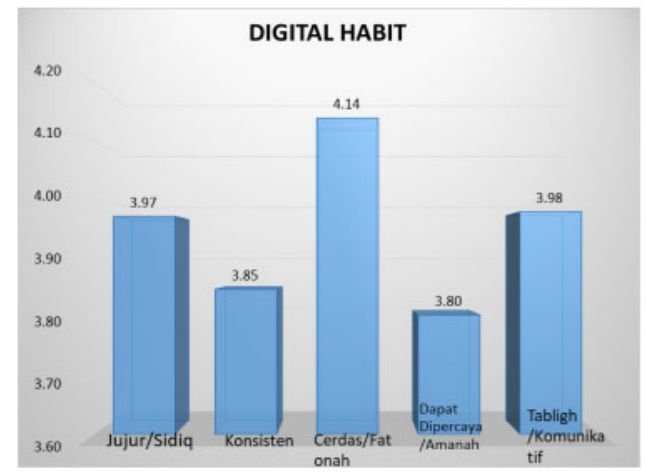

Figure 1. Youth digital habit (digital skill). (Source: compiled by Researchers 2018).

Digital skills need to be mastered by creating $\mathrm{Z}$ in the 21 st century to dominate the competitive world (Velden 2012). This is in line with the shift in the industrial society toward an information and knowledge society, which has implications for the mastery of various skills needed in job placement and the world community (Voogt \& Roblin 2010). Based on the research findings, education has a role in preparing the skills and competencies of adolescents in facing the digital era. Trilling and Fadel (2009) revealed that three 21 st century competencies are often referred to as "the rainbow of 21 st-century knowledge skills": life and career skills; learning and innovation; and media and information technology. The digital habits of adolescents are determined by the extent to which they can demonstrate aspects of universal and responsible positive behavior as values and characters that everyone needs to have, e.g., honesty, firm in upholding consistency (istiqomah), intelligence (fathonah), disbelieving (mandate), and a conveyor of values (tabligh). Diagrammatically, the habits of digital youth can be seen in Figure 1.

Based on Figure 1, the digital habits of adolescents, including honesty (sidiq), consistency (istiqomah), intelligence (fatonah), trustworthiness, and communicative/convey good things (tabligh) are in the high category. The value of honesty is 3.97 , consistency 3.85 , intelligence 4.24 , trustworthiness 3.80, and communicative/conveying good things 3.98, while the average value is 3.95. The habit of being honest in adolescents is shown by the habit of providing correct and impartial information. Adolescents' persistence is demonstrated by five characteristics: relying on one's abilities, the courage to admit mistakes, the courage to obey school rules, studying seriously, and always upholding principles in relationships. Intelligence (fatonah) in using the internet/social media based on the habit of asking questions about things not understood, being able to select and sort information, and respecting differences in beliefs. Intelligence in choosing news and opinions on social media must be accompanied by the ability to present real data and facts not to cause public confusion. Trustworthiness includes being brave enough to admit mistakes and being willing to apologize, not being careless, and maintaining harmony in friendship. Conveying good things (tabligh) includes sharing information according to facts and politeness in giving information. 
The five dimensions of truth values above must be developed as a benchmark for adolescent digital habits. Then, two previous components (digital knowledge and digital skills) must be understood completely and comprehensively to effectively develop good morals as digital habits. In another perspective, noble morality is equated with moral intelligence because it contains a person's ability to judge good things and bad things. Moral intelligence is seen as a person's ability to understand right and wrong, to have strong ethical beliefs, and act on these beliefs to be correct and honorable (Borba 2008). Moral intelligence is needed for kindness, strong character, and to become a good citizen. The results of the study showed that the most dominant is intelligence or fatonah. A person who has high intelligence is supported by an attitude of wanting to communicate with others coupled with an honest or sidiq character. By having a consistent nature and being trustworthy, these citizens have a sense of responsibility. There is an oddity in this finding, that honesty is supported by intelligence and others follow.

To face the 21 st century, the competence of citizens that needs to be improved includes increasing awareness, understanding, and legal awareness. The millennial generation tends to use digital technology in various aspects of life. Therefore, forming citizens is on a legal understanding in IT to prevent cyberlaw (IT crimes). In today's digital era, the values that must be upheld are tolerance and caring for others following the second principle of Pancasila, namely fair and civilized humanity. Jeffery (2012) revealed that the value of humanity is one of the obligations as citizens of the world, that is respect for the rights of others and tolerance. Insulting and defaming other people, including deception to others in any national society, is not justified, especially in cyberspace where individuals can easily access and influence the perceptions of others.

Advances in information and communication technology must be useful for the welfare of the community. This technology is a tool to create an intelligent and advanced nation. The Internet can provide immense benefits to education, research, commerce, and other aspects of life. Citizens who are civilized in the digital era should use technological devices that can be used according to their designation as a mirror of digital society (digital citizenship) that upholds civilized values, awareness of brotherhood and humanity, supports human rights, makes themselves citizens with dignity as a human being, and there is also a balanced attitude between local interests (local awareness) such as love of family, ethnic identity, awareness of the community and self-interest, and global interests such as universal awareness of human equality and obedience to the constitution in each of its actions as manifestations in the second principle of Pancasila, which is a just and civilized humanity. Aristotle in Heater D. (2004) said that if citizens behave and follow the constitution, they can be said to be good citizens. Still, good humans do not see the state because, basically, humans are right from their conscience. This means that the behavior and attitudes of good citizens in the digital era are based on their conscience.

Indonesia has different characteristics in fostering civilized citizens in the digital era. Based on the objectives of national education, article 3 of Law No.20/2003 concerning the National Education System imperatively outlines that: national education functions to develop abilities and shape the character and civilization of a nation with dignity to educate the life of the country, aimed at developing the potential of participants educated to become human beings who believe and fear the Almighty God, have a noble character, are healthy, knowledgeable, capable, creative, independent, and become democratic and responsible citizens. Things to be developed are noble and intelligent characters in the use of social media. Efforts in forming civilized citizens in the digital era are not only able to understand but are able to show morality, intelligence, tolerance, caring, and human value development that can be done through social media.

Social media is very influential in various kinds of decision making. On the other hand, this digital era must be able to form smart citizens. Smart in choosing information and smart in providing information. Van Dijk's (2011) writing showed that citizens of countries such as Korea, China, and the United States must be cultivated or well educated in the current era of globalization, an are not easily influenced by information alone. This is reinforced by the opinion of Cogan and Derricot (1998) that global citizens must have several multidimensional national characteristics, namely: (a) the ability to understand, accept, and respect cultural differences; (b) the ability to think critically and 
systematically; and (c) the ability to resolve conflicts peacefully without violence. Such characters are necessary for citizens in the digital age. The development of information, communication, and technology is one of the causes of the world revolution (Waters in Sunarto 2004). That is the importance of rebuilding noble morals for young citizens in the digital era.

\section{CONCLUSIONS AND IMPLICATIONS}

Digital citizenship in Indonesia needs to be upgraded to digital etiquette and digital law competencies toward good and intelligent digital citizens. The strategy was undertaken to realize it through the power of groups in social media "who controls social media, he controls the world". The implications of this research are to reconstruct the rules (UU ITE) in the usage and users of social media and the appropriate education model for digital citizens. It focuses on freedom of opinion, which still has multiple interpretations.

\section{ACKNOWLEDGMENT}

Gratitude is given to the Directorate of Research and Community Service of Telkom University who provided facilities that helped in the research process. Contributions from each author-first author: research conduct and design early writing; second author: writing language and content.

\section{REFERENCES}

Bernier, A. 2008. Making Space for Young Adults: Three Stages Toward Success. Montreal: San Jose State University.

Buckingham, D. 2000. The Making of Citizens: Young People, News and Politics. London and New York: Routledge.

Budimansyah, D. 2008. Membangun Karakter Bangsa Di Tengah Arus Globalisasi dan Gerakan Demokratisasi: Reposisi Peran Pendidikan Kewarganegaraan. Inauguration speech of Professor of Civic Education, Social Studies, IKIP, Bandung.

Budimansyah, D. and Suryadi, K. 2008. PKn dan Masyarakat Multikultural. Bandung: Study Program of Civic Education, Graduate School Universitas Pendidikan Indonesia.

Chapman, J.A. and Robertson, M. 2015. Youth Leisure, Places, Spaces and Identity. New York.

Cloudry et al. 2013. Digital citizenship? Narrative exchange and the changing terms of civic culture. http://www.tandfonline.com/loi/ccst20

Cogan, J.J. 1998. Citizenship for the 21 Century: An International Perspective on Education. London: Cogan Page.

Djahiri, A.K. 2006. Esensi Pendidikan Nilai Moral dan Pendidikan Kewarganegaraan di Era Globalisasi. Bandung: Civic Education Laboratory, Faculty of Social Studies, Universitas Pendidikan Indonesia.

Komalasari, K. 2009. The Effect of Contextual Learning in Civic Education on Students' Civic Competence. Journal of Social Sciences 5(4):261-270.

Komalasari, K. (2017). Value-Based Interactive Multimedia Development through Integrated Practice for the Formation of Students' Character. The Turkish Online Journal of Educational Technology 16(4).

Machfiroh, R. 2016. Digital Citizenship. Research final report: Telkom University.

Machfiroh, R. et al. 2017. The 2nd International Conference on Sociology Education. DOI: 10.5220/ 0007107408730877

Saripudin, D. and Komalasari K. 2015. Living Values Education in School's Habituation Program and Its Effect on Student's Character Development. The New Educational Review 39:51-62.

Van Dijk. 2015. Presentation on Sharing Session at Directorate of Research and Community Service, Telkom University, August 13, 2015. 